\title{
1. Common law and public domain approaches to water governance - an Australian perspective ${ }^{1}$
}

\section{Douglas Fisher}

\section{INTRODUCTION}

Access to water and use of water are critical issues for individuals, corporate and institutional entities, all levels of government and nation states. The legal arrangements for water resources governance are equally critical: in particular, who controls access and use and according to what criteria. Is it the nation state in the exercise of rights of sovereignty; a public sector entity in the exercise of civil law, common law, codified or statutory rights; a group of individuals who are part of an interested community in the exercise of rights of common; or an individual person or a juridical entity in the exercise of a right of property? Is the exercise of these rights limited in any way? What is the nature of these rules?

There are perhaps three ways of responding to these questions. These responses reflect the characteristics of the relevant legal arrangements: those based on practice and custom; a rules based system according to which the content of these rules is public knowledge; and an administration based system according to which the content of each person's rights and duties is determined by a public sector agency exercising a discretion or in accordance with a set of criteria of which there is public knowledge. These are complex and intellectually demanding questions that invite a discussion of a range of normative and legal issues. This chapter seeks to address these issues in their wider context and more

1 This chapter builds upon material discussed in Fisher, Douglas Water Law (LBC Information Services 2000) (hereafter Water Law) and Fisher, Douglas The Law and Governance of Water Resources (Edward Elgar Publishing 2009) (hereafter Water Resources) and analyses it from the perspective relevant to this chapter. 
specifically from the perspective of the way the legal arrangements in Australia have developed in different ways over the years.

\section{THE DOCTRINAL FOUNDATIONS OF WATER AS A COMMON RESOURCE - A COMPARATIVE PERSPECTIVE}

\subsection{Water as a Common Resource in International Law $^{2}$}

The normative and legal issues mentioned in the abstract have arisen not fortuitously but rather as a result of a range of hydrological, geographical, ecological, economic, social, cultural and political factors. Although international law in its current form is a relatively recent phenomenon, its acknowledgement of water as a common resource is a current reflection of the doctrinal debate that has occurred over thousands of years. A brief review of water as a common resource in international law is a useful point of commencement of this wider review of the doctrinal foundations of water as a common resource.

An international watercourse may flow through two or more nation states whose need for and use of the water may differ considerably. The use by the upstream state may impact upon the needs of the downstream state and vice versa. Similarly states adjacent to an inland lake may have competing interests in the water. Out of these circumstances there emerged in international law the doctrine of a community of interest. As early as 1911 the Madrid Declaration, an unauthoritative instrument of the Institute of International Law, recognised that 'riparian states with a common stream are in a position of permanent physical dependence on each other which precludes the idea of the complete autonomy of each state in the section of the natural watercourse under its sovereignty'. ${ }^{3}$

States have always enjoyed the capacity to negotiate a consensual arrangement about the use of these shared water resources. In the absence of such an agreement between states, the international judiciary was originally hesitant to impose restrictions on the exercise of their sovereignty. However, as early as 1985 the approach of the international judiciary was summarised in this way:

2 Fisher, Water Resources (n 1), 114-22, 192-3.

3 Food and Agriculture Organisation of the United Nations, 'International Regulation regarding the Use of International Watercourses for purposes other than Navigation' in Sources of International Water Law (Food and Agriculture Organisation 1998), 269-70. 
The common import of all these decisions is that where a river flows between two or more states or similar entities, each of those states or entities has a vital interest in the waters of the river and none has an absolute right to them; consequently, every state must, in the exercise of its sovereignty, consider the needs of the neighbouring state. ${ }^{4}$

The idea of water as a shared or common resource had become the basis of the approach of international law to the governance of water resources.

But according to what criteria were the needs of neighbouring states to be determined? In 1958, the International Law Association introduced the doctrine of reasonable and equitable use in these terms:

Except as otherwise provided by treaty or other instruments or customs binding upon the parties, each co-riparian state is entitled to a reasonable and equitable share in the beneficial uses of the waters of the drainage basin. What amounts to a reasonable and equitable share is a question to be determined in the light of all the relevant factors in each particular case. ${ }^{5}$

It was not until 1997 that this approach was formalised by the Convention on the Law of the Non-navigational Uses of International Watercourses $^{6}$ which entered into effect in 2014. The fundamental principle stated in article 5(1) provides:

Watercourse states shall in their respective territories utilize an international watercourse in an equitable and reasonable manner. In particular, an international watercourse shall be used and developed by watercourse states with a view to obtaining optimal and sustainable utilization thereof and benefits therefrom, taking into account the interests of the watercourse states concerned, consistent with adequate protection of the watercourse.

Structurally, this limitation on the exercise of sovereign rights comprises four duties: a duty to use in an equitable and reasonable manner; a duty to use and develop with a view to obtaining optimal and sustainable utilisation; a duty to take into account the interests of watercourse states;

4 Godana, B.A. Africa's Shared Water Resources (Francis Pinter Publishers 1985), 47-8.

5 Food and Agriculture Organisation of the United Nations, 'Resolution on the Use of the Waters of International Rivers' in Sources of International Water Law (Food and Agriculture Organisation 1998), 285-6.

6 Convention on the Law of the Non-Navigational Uses of International Watercourses 1997 (1998) International Legal Materials 36, 700-718. 
and a duty for the utilisation of a watercourse to be consistent with its adequate protection. ${ }^{7}$

What emerges is a rules-based system for the governance of international watercourses. There is no involvement of international institutional decision makers. The states in question decide how to comply with these rules subject only to a judicial determination of any dispute. Water in these circumstances has become a shared or common resource capable of use in accordance with a set of rules formulated in general but objective terms and able in accordance with the supporting provisions in the Convention to be applied in specific circumstances.

\subsection{The Range of Approaches to Water as a Common Resource}

These rules of international law are of recent origin. Do they represent a new doctrinal approach or are they reflective of ancient doctrine? Individuals as such or as members of a group have been using water to which they have access since time immemorial. The source of these arrangements has variably been practice, custom, judicial recognition or a code. In modern parlance this has been the outcome: 'most natural resource systems used by multiple individuals can be classified as common-pool resources.' 8

What is the legal position when the individual accesses the common pool and uses the resource? It has been described in this way in relation specifically to water:

While water in a stream channel, a lake or sea, or an underground aquifer appears as an undifferentiated mass resource - the quintessential 'common pool' - water extracted from the surface or underground body is an alienable quantity. It can be stored, measured, transported, even bought and sold as a commodity, and consumed. A quantity of water captured for consumption by one user is unavailable to another user, at least, until it is returned to the body of water from which it was taken. ${ }^{9}$

The critical question is the set of rules according to which the water can be extracted. Who has the right to extract: any member of a group, a

7 Fisher, Water Resources (n 1), 121.

8 Ostrom, E. 'Reformulating the commons' in Joanna Burger, Elinor Ostrom, Richard Norgaard, David Policansky and Bernard D. Goldstein (eds), Protecting the Commons (Island Press 2001), 18.

9 Schalger, Edella and Blomquist, W. 'Water resources: the southwestern United States' in Joanna Burger et al. (eds), Protecting the Commons (Island Press 2001), 134-5. 
particular member of a group, the riparian landowner, the surface landowner, or a person authorised by a regulatory entity to do so? The reference to 'owner' immediately acknowledges the relevance of the complex notion of property. ${ }^{10}$ And are there any limitations on the exercise of the right or on the grant of authority? The answer depends upon the specific rules of the legal system in question. A number of examples illustrate the range of approaches.

\subsection{The Structure of Chinese Law ${ }^{11}$}

The approach according to early Chinese law was a combination of custom and central administration. A 'sophisticated administrative system linked the Emperor with the local community of users'.12 But if this system provided no solution, then 'ancient usages and precedents' 13 filled the gap. Thus individuals had no rights - only duties. In this way, 'everyone seems to have had duties, with rights reduced to the positive manifestation of other people's duties'. ${ }^{14}$ The governing principle of Chinese law has been 'water equalization'.15 This was realised by the imposition of a range of duties on regulators, distributors and users alike: ${ }^{6}$ for example, the duty to provide one's labour for one month during the year at the disposal of the administration. ${ }^{17}$ The sanctions for breach of the duties were penal. This approach has remained in place. Thus 'the basic principles of water equalization, punishment for offences relating to waters and responsibility of local officials, persist up to modern times'. ${ }^{18}$

\subsection{The Focus of Islamic Law ${ }^{19}$}

Although Islamic water law has been codified, 'the arrangements for managing water resources in Islamic countries have traditionally been

10 Fisher, D. 'Rights of property in water: confusion or clarity' (2004) Environmental and Planning Law Journal 21(3), 200-226.

11 See generally Fisher, Water Resources (n 1), 78, 80-81, 163-4.

12 Caponera, D.A. 'Water law principles in the Chinese legal system',

(1960) Indian Journal of International Law, 263.

13 Ibid.

14 Ibid., 248.

15 Ibid., 250, 252.

16 Ibid., 250, 255.

17 Ibid., 249.

18 Ibid., 252.

19 See generally Fisher, Water Resources (n 1), 78, 102-3, 165-8. 
very much influenced by local practice and custom and by the values stated in the Qur'an'. ${ }^{20}$ Water, it has been stated, 'lay at the heart of the legal system' ${ }^{21}$ Indeed, the word shari' $a$ meant water law rather than law in general. Out of this there developed a system of rights and duties. More particularly:

The connection between shari'a as a generic term for Islamic law, and shari'a as the path as well as the law of water, is not a coincidence, and the centrality of water in Islam is obvious in the economic as well as ritualistic sense. What is more important however, is that the jurists - the exponents and expounders of the shari'a - did not fail to develop, in answer to this centrality, a highly sophisticated system of rules. ${ }^{22}$

Thus the 'ritualistic' and moral underpinnings of this system were transformed into rules which largely comprised a set of duties based upon a duty of care owed generally to the public. This required a person 'to exercise a higher standard of care where his action adversely affects the interest of the public or may cause injury to it' ${ }^{23}$ The duties included obligations for human kind to care for the earth; not to damage the environment; not to overuse water; and to keep water free from pollution. ${ }^{24}$ It was on these foundations that Islamic law was codified.

\subsection{The Foundations of Roman Law 25}

The doctrinal foundations of Roman law acknowledge the complex notion of property. Fundamentally the holder of a right of property has exclusive access to, use of and control of the thing or res in question. Roman law classified res in four ways:

- res nullius - things belonging to no person,

- res publicae - things belonging to the state,

20 Fisher, Water Resources (n 1), 165.

21 Mallat, C. 'The quest for water use principles: reflections on Shari'a and custom in the Middle East', in J.A. Allan and Chibli Mallat (eds), Water in the Middle East: Legal, Political and Commercial Implications (Tauris Academic Studies 1995), 128.

22 Ibid.

23 Ahmad, A. 'Islamic water law as a comparative model for maintaining water quality' (2000) The Journal of Islamic Law and Culture 5, 173.

24 Ibid., 174-8; and Roughton, G.E. 'The ancient and the modern: environmental law and governance in Islam' (2007) Columbia Journal of Environmental Law 32, 6-8.

25 See generally Fisher, Water Resources (n 1), 97-8, 164-5. 
- res communes - things in which all members of the relevant group have an interest,

- res propriae or res privatae - things belonging to an identifiable person.

According to the Institutes of Justinian, res communes were the air, running water, the sea and the seashore. ${ }^{26}$ Classical Roman law during the republic recognised a close relationship between land and water. ${ }^{27}$ 'Thus water physically connected with public land was aqua publica and water physically connected with private land was aqua privata or aqua propria.' 28

It was, however, access rather than ownership that lay at the foundations of this system. Accordingly:

Rivers were regarded as public things if they were perennial, i.e. normally flowing all the year round. Although such a river could not be owned, its beds and banks could be; but it seems that the riparian owners (i.e. the owners of the river banks) could not prevent the public from using the banks to enjoy the river. Remedies were normally available to protect the enjoyment or use of public things. ${ }^{29}$

If so, rivers as res publicae disclosed some of the features of res communes. In any event, it may be concluded that rivers - running water according to Justinian - were regarded as common or shared resources. But this governance system changed.

During the later years of the Roman empire, this system of water resources governance based upon public waters controlled by the state and private waters controlled by enforceable legal rules was increasingly overtaken by a system of regulation based upon the administrative grant of rights in relation to water. ${ }^{30}$ In other words, an administration based system was substituted for a rules based system of public and private rights in relation to water. Although the system may have continued to recognise water as a common or shared resource, the instruments for its management evolved over time.

26 Sanders, T.C. Institutes of Justinian (2nd edn, Parkes \& Son 1859), $167-70$.

27 Caponera, D.A. Principles of Water Law and Administration (A.A. Balkema Publishers 1992), 31.

28 Fisher, Water Resources (n 1), 97.

29 Borkowski, A. and du Plessis, P. Textbook on Roman Law (3rd edn, Oxford University Press 2005), 172.

30 Caponera (n 27), 40-43. 


\subsection{The Evolution of Public Domain Regimes ${ }^{31}$}

If, as noted in the previous paragraph, waters increasingly became a matter of public administration towards the end of the Roman empire, the rules developed as a system based upon the concept of the public domain. Consistently with this approach, in the eighteenth century a Scottish court based its decision on what it perceived to be the public interest. ${ }^{32}$ Underlying these paradigms is the idea of water as a common resource. But how is a common resource to be managed? The outcome of a management system based on this idea is likely to be a set of specific rights and duties attached to a range of individuals and institutions, both public and private, and based upon what is perceived to constitute the public interest. What is the public interest may be left to the person or institution making the decision or determined in accordance with a set of publicly available criteria. It is the legal system which creates the point of commencement of such a system. It may be a set of common law rules or an administrative system managed by a public sector agency. The outcome is a set of rights and duties. Such a system is often described as a public domain regime.

The doctrine of the public domain takes water in its natural location out of any trading regime. It thus becomes a res extra commercium. ${ }^{33}$ The instruments for its management are variable and include: state ownership; public ownership; public trusteeship; and exclusive public control. ${ }^{34}$

Water resources in France are recognised as an element of le patrimoine commun de la nation. ${ }^{35}$ More specifically, article 538 of the French Civil Code of 1804 declared that 'rivers or streams which will carry floats ... which are not susceptible of private ownership are considered as dependences on public domain'. ${ }^{36}$ The owners of land through, under or across which water flowed had rights conferred and controlled by the civil code. In Italy navigable and non-navigable streams were declared to be public waters but subject to the right of riparian

\footnotetext{
31 See generally Fisher, Water Resources (n 1), 235-6, 243-50.

32 For details about this decision see the discussion in later paragraphs about the influence of the civil law on the development of the common law.

33 Fisher, Water Resources (n 1), 243.

34 Ibid.

35 Salman, S.M.A. and Bradlow, D.D. Regulatory Frameworks for Water Resources Management: a Comparative Study (World Bank 2006), 57.

$36 \mathrm{Hu}, \mathrm{D}$. Water Rights: an International and Comparative Study (IWA Publishing 2006), 24; and Planiol, M. Treatise on the Civil Law: Volume 1, Part 2 (Louisiana State Law Institute with the authority of Libraire Generale de Droit et de Jurisprudence Paris tr, 12th edn, Louisiana State Law Institute 1939), 437.
} 
landowners to use non-navigable streams for irrigation and industry provided certain conditions were satisfied. ${ }^{37}$ In Spain all water resources are owned and controlled by the state with two exceptions: groundwater under private land and surface waters other than rivers and streams originating on the land of the landowner. ${ }^{38}$

An alternative to state or public ownership is public trusteeship, as in South Africa, where the national government is by statute the "public trustee of the nation's water resources' ${ }^{39}$ In Germany, the regulatory framework for water resources governance gives to the state - at either federal or Lander level - exclusive control over them. ${ }^{40}$ The public domain thus provides for the management of water resources at their source in various ways that fundamentally reflect what is perceived to be the public rather than an individual interest.

These public domain regimes exist alongside the civil codes which create a set of liability rules to compensate for the unlawful consequences of the use of water. In much the same way, common law regimes incorporate sets of rules granting rights of access and of use to individuals and distributing liability in the event of injury or damage to the interests of affected members of the community. The principal difference between the two systems is that in the public domain system rights are granted administratively, while in the common law system rights exist in accordance with a set of rules which are a matter of public knowledge. This is an important difference in practice. Under the common law it is the responsibility of the individual to decide what are the relevant rights and duties in any particular set of circumstances and to ensure compliance with them. Under the public domain system, it is the responsibility of a public sector agency to determine what are the relevant rights, to grant these rights formally and to inform the individual accordingly.

37 Food and Agriculture Organization, Water Laws in Selected European Countries (Food and Agriculture Organization of the United Nations 1975), 119.

38 Dzurik, A.A. Water Resources Planning (Rowman and Littlefield Publishers Inc. 1990), 41.

39 Fisher, Water Resources (n 1), 245-6.

40 Salman and Bradlow (n 35), 61. 


\section{THE DEVELOPMENT OF DOCTRINAL FOUNDATIONS OF THE COMMON LAW IN RELATION TO WATER RIGHTS ${ }^{41}$}

\subsection{Water Rights as Natural Rights}

The relationship between land and water - jointly or separately - has influenced the development of English law. In 1625 the acquisition of water rights was judicially determined not to be a right incidental to the possession of land. ${ }^{42}$ It was commented that "the question here is of aqua profluens' ${ }^{43}$ and two consequences followed:

- 'water hath its natural course, and natura sua descendit, and it may be called usu captio or usage', ${ }^{44}$

- 'where the thing hath its being by prescription, unity will extinguish it; but where the thing hath its being ex jure naturae, it shall not be extinguished. ${ }^{45}$

Rights in relation to water were accordingly natural rights and, by implication, could be acquired by usage. This led to an acknowledgement of the appropriation doctrine favoured by the philosopher John Locke. ${ }^{46}$ According to Blackstone the consequence in terms of legal doctrine was that 'If a stream be unoccupied, I may erect a mill thereon, and detain the water; yet not so as to injure my neighbour's prior mill, or his meadow; for he hath by the first occupancy acquired a property in the current.' ${ }^{37}$ Thus there emerged a set of rules comprising a combination of protectable rights and enforceable duties. This approach was judicially endorsed in 1831. 'By the law in England, the person who first appropriates any part of the water flowing through his land to his own use, has the right to the use of so much as he thus appropriates, against any other.' ${ }^{38}$ The

41 See generally Fisher, Water Law (n 1), 64-74; Fisher, Water Resources (n 1), 98-101, 168-72.

42 Sury v Pigot (1625) English Reports, 79, 1263.

43 Ibid., 1266.

44 Ibid.

45 Ibid., 1267.

46 Fisher, Water Resources (n 1) 99.

47 Blackstone, W. (1765 to 1769), Commentaries on the Laws of England (edn of 1809, Professional Texts Ltd) 403.

48 Liggins v Inge (1831) English Reports, 131, 268. 
doctrine of appropriation was thus confirmed but it was soon to give way to the riparian doctrine.

\subsection{The Influence of the Civil Law}

In 1851 the Court of Exchequer ${ }^{49}$ was presented with a choice: to continue with the notion of water as a right ex jure naturae and capable of acquisition by appropriation - an individual rights approach - or to adopt the approach embraced by the law of Scotland which was based on the principles of the codified Roman law and which recognised water as a shared or common resource - a community rights approach. The reasoning of the Court of Session in the case of $1768^{50}$ was considered in detail by the Court of Exchequer. This was the reasoning of the Scottish court:

A river, which is in perpetual motion, is not naturally susceptible of appropriation; and were it susceptible, it would be greatly against the public interest that it should be suffered to be brought under private property. In general, by the laws of all polished nations, appropriation is authorised with respect to every subject that is best enjoyed separately; but barred with respect to every subject that is best enjoyed in common. Water is scattered over the face of the earth in rivers, in lakes etc. and for the use of animals and vegetables. Water drawn from a river into vessels or into ponds becomes private property; but to admit of such property with respect to the river itself, considered as a complex body, would be inconsistent with the public interest, by putting it in the power of one man to lay waste a whole country. ${ }^{51}$

This was the conclusion of the Scottish court:

A river may be considered as the common property of the whole nation; but the law declares against separate property of the whole or part. 'Et quidem naturali jure communia sunt haec, aer, aqua profluens et mare.' A river is a subject composed of a trunk and branches. No individual can appropriate a river, or any branch of it; but every individual of the nation, especially those who have land adjoining, are entitled to use the water for their private purposes. $^{52}$

\footnotetext{
49 Embrey v Owen (1851) Exchequer, 6, 353.

50 Magistrates of Linlithgow v Elphinstone (1768) Morison, 15, 12805-case

51 Ibid., para. 3.

52 Ibid., para. 4.
} no 28 . 
This consists of these elements: flowing water as a common resource; flowing water as common property; every individual has a right to use the water; riparian land owners in particular have a right to use the water; and water extracted in accordance with these rules becomes private property. It is not surprising that, given the civil law context of the law of Scotland, this approach reflected the law of imperial Rome.

\subsection{The Emergence of the Riparian Doctrine}

Which approach did the Court of Exchequer adopt? In effect a modified version of the Scottish approach out of which emerged the riparian doctrine. It was accepted that flowing water was not the subject of a right of property. There was, however, a link between water and land. Thus 'the right to have the stream to flow in its natural state without diminution or alteration is an incident to the property in the land through which it passes. ${ }^{53}$ And consequently 'each proprietor of the adjacent land has the right to the usufruct of the stream which flows through it.' 54

How was this usufructuary right characterised in the absence of a right of property in flowing water? Here is the answer. 'Flowing water is publici juris, not in the sense that it is bonum vacans, to which the first occupant may acquire an exclusive right, but that it is public and common in this sense only, that all may reasonably use it who have a right of access to it.' 55

This is a rejection of a comprehensive appropriation doctrine because the usufructuary right is limited in two ways:

- to those who have access to the water,

- to use it reasonably.

It will be recalled that the Scottish court extended the usufructuary right to every individual - including the riparian occupiers. The English court effectively limited it to riparian occupiers, a subtle but important difference. The flowing water may therefore be regarded as a common resource or possibly even common property - a res communis - but whose usufructuary right is restricted to the group of individuals with a lawful right of access - the riparian landowners.

Water not only flows through a watercourse but also percolates underground and flows across the surface of land. The owner or the

\footnotetext{
53 Embrey v Owen (n 49), 369.

54 Ibid.

55 Ibid.
} 
lawful occupier of the land in each of these two sets of circumstances has a similar usufructuary right in relation to the water - underground or surface. It was explained judicially in 1885 in these words:

No one has at any time any property in water percolating below the surface of the earth, even when it is under his own land, but it is equally clear that everybody has a right to appropriate that percolating water, at least whilst it is under his own land, to the extent that he may take it all so as to prevent any of it going on the land of his neighbour. ${ }^{56}$

The neighbour has a similar right. Why? 'This percolating water below the surface of the earth is therefore a common reservoir or source in which nobody has any property, but of which everybody has, as far as he can, the right of appropriating the whole.' 57

\subsection{The Challenges for the Common Law of Public Water Supply}

\subsubsection{Introduction}

It will be recalled that the Court of Exchequer in 1851 had limited the exercise of the riparian right in two ways: first, to those with lawful access to the water and, second, to use the water reasonably. ${ }^{58}$ The second became more problematic. It became an issue for the House of Lords in 1859.59 Large quantities of underground water were extracted to provide a public water supply to a small township. In the circumstances this was held to be lawful in exercise of the right of appropriation available to the owner of the surface of the land to extract water moving indiscriminately and in an unknown and undefined way below the surface of the land. But Lord Wensleydale had reservations. There was no doubt about the right to sink the relevant well. But:

According to the rule of reason and law, 'sic utere tuo ut alienum non laedas', it seems right to hold that he ought to exercise his right in a reasonable manner, with as little injury to his neighbour's rights as may be. ${ }^{60}$

A supply of water for the landowner's own operations would have been reasonable.

\footnotetext{
56 Ballard v Tomlinson (1885) Chancery Division, 29, 120.

57 Ibid.

58 Embrey v Owen (n 49), 369.

59 Chasemore v Richards (1859) House of Lords Cases, 7, 349.

60 Ibid., 388.
} 
But I doubt very greatly the legality of the defendant's acts in abstracting water for the use of a large district in the neighbourhood, unconnected with his own estate, for the use of those who would have no right to take it directly themselves, and to the injury of those neighbouring proprietors who have an equal right with themselves. ${ }^{61}$

According to the approach of Lord Wensleydale, two conditions for the application of the riparian doctrine under the common law were required to be satisfied:

- the existence of a right of access to the water,

- the requirement for the use of the water to be reasonable.

The approach of the common law was to a limited extent modified by the arrangements for public water supply introduced in England during the late eighteenth century and enduring to varying extents for two hundred or so years. Individual entrepreneurs - personal or more likely corporate - presented a private bill to Parliament inviting it to enact a provisional order approving a particular project: in effect legislation authorising a particular project sponsored by the private or in some cases the public sector. ${ }^{62}$ The projects were frequently major infrastructure developments - some involving water resources. The relationship between these statutory rules and the traditional common law rules was an issue for the House of Lords in 1875 in the Swindon Case. ${ }^{63}$

\subsubsection{The background to the Swindon Case}

One of the litigants in this case was a canal company which had, since 1795, statutory authorisation to construct and maintain a canal and to supply the canal with water taken from sources within 2000 yards of any part of the canal. These arrangements were confirmed by complementary legislation in 1813 and 1821. In 1807 the company bought a mill on the banks of one of these watercourses and so became a riparian proprietor. The company accordingly had statutory and common law rights to water to support its activities in relation to the canal. The other litigant was a waterworks company registered under the Joint Stock Companies Act 1862 and established to supply water to the town of Swindon. This

61 Ibid., 389.

62 Hood Phillips, O., Jackson, P. and Leopold, P. O. Hood Phillips \& Jackson: Constitutional and Administrative Law (8th edn, Sweet \& Maxwell 2001), 249-50.

63 Swindon Waterworks Company $v$ Wilts and Berks Canal Navigation Company (1875) Law Reports Hose of Lords, 7, 697. 
company bought a mill on the banks of the same watercourse as the canal company but upstream of the location of the mill bought by the canal company. This company enjoyed common law riparian water rights but not statutory rights. The waterworks company was thus an upstream riparian proprietor and the canal company a downstream riparian proprietor.

The circumstances giving rise to the litigation are indicative of the relationship between the environment and economic development in nineteenth-century England. The waterworks company extracted water from the river to provide a public supply to Swindon. The canal company extracted water to ensure enough water in the canal to enable successful navigation. 1870 was an eventful year:

The year 1870 was, no doubt, a year of unusual drought; but in that year ... the supply of water to the canal was undoubtedly defective. Heavy traffic traffic of barges laden heavily, requiring a large draught of water - had to be refused on account of the insufficient supply of water in the canal ... How did that deficiency of supply arise? No doubt the evaporation and absence of influx owing to the dryness of the season had something to do with that. But it stands upon the evidence ... that a considerable reason for the deficiency of the supply was, that at that very time the [waterworks company] had taken possession of the upper part of the waters of the stream and diverted those waters for the supply of Swindon. ${ }^{64}$

The conclusion was that '[t]he supply of water for the canal, arising out of the stream, was deficient, and was made deficient by, or at all events partly by, the acts of the [waterworks company]'. ${ }^{65}$ But were the acts of the waterworks company illegal?

\subsubsection{The rights of the waterworks company in the Swindon Case}

The waterworks company relied upon their rights as a riparian proprietor under the common law to justify their actions. It will be recalled that in the case of Chasemore ${ }^{66}$ the source of the water supplied to the town for public use was an underground source and the extraction determined to be legal. But Lord Wensleydale had reservations and introduced a test of reasonability. The right of a riparian proprietor to extract and use water was not absolute. In the Swindon Case ${ }^{67}$ Lord Cairns noted that the uses

\footnotetext{
64 Ibid., 707.

65 Ibid., 707.

66 Chasemore v Richards (n 59).

67 Swindon Waterworks Company $v$ Wilts and Berks Canal Navigation
} (n 63). 
to which the water may be put by the upper owner' 68 were required to be 'uses connected with the tenement of that upper owner', ${ }^{69}$ for example, for irrigation or manufacturing. What about public supply? The lengthy response of Lord Cairns is worthy of note:

But the use which here has been made by the [waterworks company] of the water, and the use which they claim the right to make of it, is not for the purpose of their tenements at all, but is a use which virtually amounts to a complete diversion of the stream - as great a diversion as if they had changed the entire water-shed of the country, and in place of allowing the stream to flow towards the south, had altered it near its source, so as to make it flow towards the north. ${ }^{70}$

On the basis of this factual analysis, Lord Cairns placed the issue in its legal context:

That is not a user of the stream which could be called a reasonable user by the upper owner; it is a confiscation of the rights of the lower owner; it is an annihilation, so far as he is concerned, of that portion of the stream which is used for those purposes, and that is done, not for the sake of the tenement of the upper owner, but that the upper owner may make gains by alienating the water to other parties, who have no connection whatever with any part of the stream. ${ }^{71}$

The relevant test was thus reasonability. Not a surprising conclusion given its pivotal function in the common law.

\subsubsection{The relevance of the statutory rights of the canal company in the Swindon Case}

The canal company, whose rights under the common law had been infringed, was vested with statutory rights in relation to the water in question. Were they relevant? The legislation establishing the canal company, it will be recalled, authorised the company to 'supply the canal with water' from the sources stated in the legislation and situated within 2000 yards of the canal. This statutory power was exercised by the company. Lord Cairns concluded that 'the canal proprietors had the right then and there to take that water for the supply of their canal.' 72

\footnotetext{
68 Ibid., 704.

69 Ibid., 704.

70 Ibid., 704-705.

71 Ibid., 705.

72 Ibid., 706.
} 
The critical words were 'for the supply of their canal'. The use of the water for this purpose may not have been a use recognised by the common law riparian doctrine - a point not decided by the House of Lords. It was clearly a use authorised by the legislation. But if the taking of the water for such a use 'stopped it from flowing in its accustomed course to any tenement lower down upon its course, [the canal company] would be obliged to compensate the owner of that inferior tenement under their Act of Parliament. ${ }^{\prime 3}$ In this respect common law liability and statutory liability were much the same. But this was not the relationship between the litigants in this case. The waterworks company was the upper riparian proprietor and the canal company the lower riparian proprietor. Hence liability was determined in accordance with the common law simply because both companies were riparian proprietors. The analysis by Lord Cairns of the canal company's statutory rights - strictly obiter dicta - is nevertheless particularly illuminating.

Lord Hatherley developed this point in a rather significant way. Although both companies were riparian proprietors, the existence of the canal company's statutory authority to take and use the water to supply the canal gave 'to the canal proprietors a particular right'. ${ }^{74}$ What was the substance of this particular right? Here is the answer:

For the purpose in question, namely, the making of the canal and the keeping it filled from time to time, either in its then state or in its enlarged state ... and either for the existing navigation, or for any navigation which might come on it, they were entitled to have this canal adequately and properly supplied with water. ${ }^{75}$

The amount of water to be available for this purpose was not, as it had been argued under the common law riparian doctrine, restricted in any way. Why?

The answer is that the Legislature has not so limited the supply [to so many thousand gallons a day], and therefore the Legislature not having so limited it, we must take the larger purpose for which it was granted, namely, the continuous use of the water for the purposes of navigation. In that case the canal company would have the right which every riparian proprietor would have, namely, a right to the flow of the stream for the purpose of satisfying their requirements. ${ }^{76}$

\footnotetext{
73 Ibid., 706-707.

74 Ibid., 711.

75 Ibid.

76 Ibid.
} 
This is a subtle combination of the statutory and common law rules. As a riparian proprietor, the canal company had the right to extract and use the water for the purposes recognised by the common law. As the holder of the rights conferred by the legislation, the canal company had the common law right extended to include the purposes stated in the legislation. In this case the waterworks company's activities were governed only by the common law which did not recognise the public supply of water as a lawful use. Although the activities of the canal company were not directly an issue, the existence of statutory rights might well in appropriate circumstances have proved critical. This case demonstrates that the legal arrangements in England to support the achievement of public purposes in managing water resources tended to be project based and ad hoc rather than based upon appropriate doctrinal foundations other than the common law which did not directly address these issues. The response in other jurisdictions, already noted in previous paragraphs, has been quite different - the recognition of public domain regimes.

\section{WATER GOVERNANCE IN AUSTRALIA BEFORE THE TWENTIETH CENTURY77}

\subsection{Water Governance by Indigenous Practices and Customs}

Before the arrival of British colonists in 1788, access to and use of water in Australia were governed by the practices and customs of the indigenous community in accordance with their ancient traditions. ${ }^{78}$ These were not uniform across the indigenous community. Individual tribes engaged in their own practices and customs. These practices disclosed a close relationship not only between water and land but also between water, land and culture. Accordingly, these rights to water could 'simultaneously contain ecological, spiritual, cultural, economic and social dimensions'. ${ }^{79}$ When native title was judicially recognised in 1992 as part of the common law and implemented by legislation in 1993, it was stated to mean quite specifically:

77 See generally Fisher, Water Law (n 1), 64-89; Gardner, A., Bartlett, R. and Gray, J. Water Resources Law (Lexis Nexis Butterworths 2009) 151-77; and Stoeckel, K., Webb, R., Woodward, L. and Hankinson, A. Australian Water Law (Thomson Reuters, Lawbook Co 2012), 13-17.

78 The information in this paragraph is derived from Gardner et al. (n 77), 534-46 and the sources therein referenced.

79 Gardner et al. (n 77), 535. 
- the communal, group or individual rights and interests in relation to land or waters:

- possessed under the traditional laws acknowledged and traditional customs observed

- where, by those laws or customs, there is a connection with the land or waters and

- that are recognised by the common law. ${ }^{80}$

This is no doubt a reflection of how indigenous rights in relation to water were traditionally perceived. The nature of indigenous rights may now be seen as essentially communal and to some extent individual: a perception far removed from the doctrines underlying the common law of England. The reception of the common law of England in 1778 rendered irrelevant indigenous water rights until their subsequent recognition by the High Court of Australia in 1992.

\subsection{The Environmental Context of Water Governance During the Nineteenth Century}

During the nineteenth century, water resources in Australia were governed in the first instance by the common law and then to the very limited extent to which the common law was varied by local legislation. It became increasingly obvious to the colonial administrators that the sources and quantity of water resources and the nature of the environment in Australia - in particular in the first colony of New South Wales were significantly different from those in the British Isles. How were the rules inherited from the English system applied in Australia during the nineteenth century - bearing in mind the climatic differences between a relatively humid climate and a relatively dry climate?

It is useful to begin with this historical perspective:

On 15 May 1788 Governor Phillip chose Sydney Cove as the landing place for the First Fleet because it was the only satisfactory site thus far encountered which appeared to have a reliable stream of fresh water. Baron Augustus Theodore Henry Alt, a well-seasoned military engineer, designed and supervised the essential buildings and public works and was largely responsible for the deepening of the river and the excavation of tanks in its sandstone bed, thereby ensuring the capacity of the 'Tank Stream' to provide Sydney's only public water supply for about 40 years. ${ }^{81}$

\footnotetext{
80 Native Title Act 1993 (Commonwealth), s. 223(1).

81 Powell, J.M. Environmental Management in Australia 1788-1914 (Oxford University Press 1976), 18.
} 
Significantly this project was designed to provide a supply of water to the public. The institutional developer of the project and the supplier of the water were the government, represented formally by the Governor.

Equally illustrative is this judicial perspective. Sources of water for private use were as important as those for public supply when the economy began to develop - particularly in relation to agriculture, cattle and sheep farming, and mining. These activities were largely those of the private sector and were based upon the rights and duties of individuals and private sector institutions. In the context of litigation between two individuals in 1867 these judicial comments illustrate the economic and social importance of water resources governance:

The subject-matter of this action is obviously of very great importance to the people of this province, where, by reason of the peculiar aridity of the climate, running water possesses special value to the cultivators of gardens and vineyards situate on the banks of creeks, as well as to the proprietors of mills worked by water-power. Hereafter, also, the question may assume a special interest to the proprietors of mines in cases where subterranean water channels may happen to be cut in the progress of mining operations. For these reasons, it has been considered fitting that on delivering judgment on this rule the law relating to watercourses should be declared by the Court. Fortunately, we have for our guidance many cases decided in the English Courts in this branch of the law. ${ }^{82}$

The Supreme Court of South Australia proceeded to do precisely that and, in doing so, reviewed many of the relevant judgments. In this case there was no relevant legislation. It was decided purely on the basis of the common law of England that applied to the rights of individuals. Would it have been different if it had involved the acquisition of water rights to provide a supply of water to the public? To answer this question requires an examination of a different set of legal rules: those relating to the reception of English law in the Australian colonies, how it was applied and how it could be modified in these colonies.

\subsection{The Rules Providing for the Reception of English Law}

The Governor of a colony as the representative of the British Crown in the colony exercised the proprietorial powers of the Crown in relation to the use of land, water and related resources. These powers were sourced in the common law. The Governor had the executive power to proclaim

82 Dunn v Collins (1867) South Australian Law Reports (Pelham), 1, 126, 135 . 
ordinances effective as enforceable rules of law. Although these arrangements originated much earlier, they were clarified judicially as late as 1889 in relation to the colony of New South Wales in a judgment of the Privy Council which indirectly, as it will be later noted, raised issues about the law relating to water governance. Lord Watson explained that 'the extent to which English law is introduced into a British Colony, and the manner of its introduction, must necessarily vary according to circumstances.' 83

The reference to 'English law' includes both the common law and statutory law. Are they treated differently or the same? Much depends on the status of the colony in question. Having determined the status of the colony of New South Wales at that time, Lord Watson went on to explain the rules for New South Wales and thus declared that 'the Crown may by ordinance, and the Imperial Parliament, or its own legislature when it comes to possess one, may by statute declare what parts of the common law and statute law of England shall have effect within its limits.' 84 There are accordingly potentially three forms of legislation: (1) statutes enacted by the Parliament of the United Kingdom; (2) ordinances promulgated by the representative of the Crown in the colony - the Governor; and (3) statutes enacted by the legislature of the colony once one has been established.

In the absence of such legislation declaring what parts of the common law and statute law of England apply in the colony, the 'law of England must (subject to well-established exceptions) become from the outset the law of the Colony, and be administered by its tribunals.' ${ }^{85}$ Lord Watson summarised the position very succinctly in this conclusion: 'In so far as it is reasonably applicable to the circumstances of the Colony, the law of England must prevail, until it is abrogated or modified, either by ordinance or statute.' 86

The language used by Lord Watson - especially the expression 'reasonably applicable' - gave to the judiciary a degree of discretion in determining what law applied in the colony. In the context of water resources governance in the colony of New South Wales the relationship between the common law of England and any relevant local legislation either ordinances or colonial statutes - became a critical issue for the courts.

\footnotetext{
83 Cooper v Stuart (1889) Appeal Cases, 14, 286, 291.

84 Ibid.

85 Ibid

86 Ibid.
} 


\subsection{The Relationship Between Common Law Rules and Statutory Rules}

\subsubsection{Introduction}

The development and construction of infrastructure facilities for the benefit of the public and the commercial sector in the United Kingdom during the nineteenth century - for example, railways, canals and to a lesser extent water supply - were for the most part authorised by legislation sponsored by the private sector or by a public sector agency in relation to a specific - sometimes a major - project. Public general legislation prescribed the procedures for such legislation but not its content. The common law appropriation and riparian doctrines enabled individual entrepreneurs to take and use the waters of rivers for their cotton and wool mills built on the banks of these rivers. In the colony of New South Wales, infrastructure facilities - especially those related to public water supply - were structured differently - no doubt because of the powers available to the Governor under the colonial system for managing land and promulgating legislation. There were traditionally three: (1) the exercise by the Crown of water rights incidental to riparian land ownership; (2) the reservation to the Crown of water rights in grants by the Crown of interests in land; and (3) the promulgation of local legislation. The doctrinal issues associated with these mechanisms are revealed by a consideration of a small number of nineteenth-century judicial decisions.

\subsubsection{The 1853 Cooper Case}

The Supreme Court of New South Wales was faced in 1853 with a dispute involving water that flowed naturally on to land in private ownership. ${ }^{87}$ The local council - Sydney Corporation, hereafter 'the council' - proposed to construct a trench on its water reserve in order to obtain water from a swamp located in the water reserve. An adjacent landowner sought an injunction to restrain the council from excavating a trench on the ground that the trench would intercept the water flowing naturally on to the adjacent land. One of the issues was whether the flow of water was temporary and casual or whether the water flowed continually and habitually between banks. If the former, the landowner had no right to any water flowing on to his land. If the latter, he had a right that there should be no interference with the flow of water and that the water

87 Cooper v Sydney Corporation (1853) Legge, 1 and 2, 765. 
should not be abstracted. The evidence on this was contradictory and the court ordered a trial of these issues.

What rules of law did the court apply? The court turned to the doctrines of the common law. Did the Crown enjoy any privileges? Were its rights the same as any other person's? The response to the first question was negative and to the second it was positive. 'The Crown, or the Corporation of the City, representing the Crown in this matter, irrespective of any powers conferred by the Legislature, can have no right, which an individual in such a case would not have.' 88 There had not been any grant of the water reserve but the council had been in possession of it for many years 'by the authority of the Crown'. ${ }^{89}$ It followed that 'they are entitled to exercise, therefore, all the rights of the Crown in respect of that land'90 and also that 'whether the Crown granted, in addition, any casual or accidental advantage, such as that of the enjoyment of water, temporarily overflowing (or which at times might overflow) from underground sources on land remaining in its possession, is to be shown.' 91

In other words, the reciprocal rights and duties of the landowner as owner and occupier of land and of the council, representing the Crown as owner and occupier of land, were the same. The landowner enjoyed a right 'to the reasonable use of the water of any perennial stream ... flowing through that land'92 but not to any temporary or casual overflow. These were the matters of fact sent for trial. The court thus applied the rules of the common law in relation to land and water by relying specifically upon the appropriation and riparian doctrines. In doing so, it reviewed many of the authoritative judgements of the first half of the nineteenth century.

There was, however, a second complicating issue: legislation authorising the council to undertake a range of works associated with the public supply of water. The language of the legislation proved critical. The council was authorised to engage in an extensive range of activities and to construct and maintain infrastructure in the broad context of what may be described generically as waterworks. This part of the judicial analysis of the legislation proved critical:

\footnotetext{
88 Ibid., 771-2.

89 Ibid., 772.

90 Ibid.

91 Ibid.

92 Ibid.
} 
They may enter upon and pass over any river, stream, road, waste lands, or street, in the City or its vicinity; and construct, and do, all such matters and things as may be deemed necessary, for making or improving such waterworks, and for bringing a sufficient supply of water for the city, provided that they shall make full satisfaction to the owners and occupiers of all lands or other hereditaments, taken, used, or injured, for all damage sustained by them by the execution of any of those powers. ${ }^{93}$

The court was impressed by the words 'bringing a supply of water to the city'. These words, it is here suggested, represent a statement of the object or outcome to be achieved as a result of the exercise of these powers. In an oblique sense it is a power to bring a supply of water to the city. Although the court did not express it in this way, a power to supply water is not a power to abstract water. The court recognised this distinction. It stated unambiguously that 'so, they may enter on and over streams; but nothing is said respecting abstracting the water from them. And waters, not being streams, it would appear, are excluded.' 94

The court thus preferred a limited rather than an unlimited interpretation of the content of the powers conferred on the council. The legislation did not authorise the abstraction of water: only the construction of water infrastructure. The legality of the council's activities in relation to the water depended upon the application of the relevant rules of the common law

\subsubsection{The 1860 Hood Case}

Seven years later the Supreme Court addressed a similar set of issues. ${ }^{95} \mathrm{~A}$ riparian landowner - hereafter 'the landowner' - carried on a woolwashing establishment on the banks of a tributary to the watercourse in question. In carrying out these activities, 'dirt and filth' were thrown into the tributary from which it went into the watercourse and then into the reservoir managed by Sydney Corporation - hereafter 'the council'. This was the response of the council:

To prevent the watercourse and reservoir being so defiled by the dirt and filth thrown into the tributary ... the [council] prevented the [upper riparian landowner] from using the tributary and watercourse for his wool-washing. By such act of the [council] almost every kind of use to which the [upper riparian landowner's] land could be put has been prevented. ${ }^{96}$

\footnotetext{
93 Ibid., 772-3.

94 Ibid., 773.

95 Hood v Sydney Corporation (1860) Legge, 1 and 2, 1294.

96 Ibid., 1295.
} 
The landowner sought compensation from the council for the loss he had sustained. On the face of it, the landowner's riparian activities had interfered with the right of lower riparian landowners to receive water of the same quantity and quality as enjoyed by upper riparian landowners. But was the council a lower riparian landowner or a public agency exercising statutory powers, or perhaps both? Significantly the powers of the council were derived from three sources: (1) as the holder of water rights reserved from a grant by the Crown; (2) as a downstream or lower riparian landowner; and (3) as the recipient of powers conferred by legislation.

Consider each in turn. In relation to the first, the land of the landowner 'was part of a large portion granted by the Crown ... by a deed, wherein the Crown reserved to itself any quantity of water and any quantity of land not exceeding ten acres on any part of the grant as might be required for public purposes'. ${ }^{97}$ The council - as representative of the Crown had taken from time to time water and portions of the land for public purposes. The council thus had an interest in the water - no doubt including its quality - recognised by the law.

Second, it was noted that, if a polluting activity had been carried on for twenty years, then 'the neighbouring riparian proprietors could be bound to endure the nuisance'. ${ }^{98}$ However, the wool-washing had not been carried on for twenty years. So the council could, according to the common law, have abated the nuisance. Significantly, in this context, the court inferred that the council had 'become possessed of land below that occupied by the [landowner in question] and so in effect have become sub-riparian proprietors'. ${ }^{99}$ Apart from any liability of the upper riparian landowner in nuisance, the landowner could be liable under the riparian doctrine because the council 'had become sub-riparian proprietors'. Accordingly, the council in that capacity 'would have been entitled to sue the[landowner] for, and restrain him by injunction from, fouling the water which they would have been entitled to receive in its natural state'. ${ }^{100}$ From the landowner's perspective, he had received no injury 'for which he could have obtained redress at common law'. ${ }^{101}$ His loss was a damnum sine injuria.

Third, what was the function of the legislation? It will be recalled that the council in this case derived its rights in relation to the water from the

\footnotetext{
97 Ibid.

98 Ibid., 1296.

99 Ibid.

100 Ibid., 1297.

101 Ibid.
} 
reservation in the Crown grant and from its status as a riparian proprietor of the land through which the watercourse flowed. The council's waterworks were constructed and managed under the Sydney Water Act 1853. The upper riparian landowner in this case sought compensation under the Act for his loss. Having decided that the loss was damnum sine injuria under the common law, the court noted that 'the question that remains is whether he is entitled to the compensation which he seeks under the Act'. ${ }^{102}$ The court once again adopted a limited rather than an expansive view of the legislation. Relying upon earlier decisions of courts in England and Scotland, here is the answer:

The compensation clauses in statutes authorising public works apply only where the act complained of is such that it would have afforded a cause of action before the act; and further that such act is authorised by the statute. Now, as the acts committed by the [council] clearly ... would not before the act have conferred a right of action to the [landowner], and as those acts are clearly authorised by the Sydney Water Act 1853, we are of opinion that the[landowner] is not entitled to succeed in this action. ${ }^{103}$

Significantly, it will be recalled, the legislation authorised the undertaking of public works. It was silent on the issue of water rights. During the nineteenth century, the colonial legislation was doctrinally secondary to the clear rules of the common law.

\subsubsection{The 1859 Lord Case}

In the 1853 Cooper Case the issue, it will be recalled, was the nature of the water rights of two adjacent landowners at common law irrespective of the status of the council as a landowner and irrespective of any statutory provisions. In the Hood Case in 1860 the statutory provisions for compensation and their relationship with the cognate rules of the common became relevant. In the Lord Case ${ }^{104}$ before the Privy Council in 1859, the question was the relationship between two related Crown grants, one of which involved water rights resumed by the council under the Sydney Water Act 1853. This Act authorised the council to 'divert, take and use' not only the waters arising from or flowing through the lands in possession of the Crown but also the waters flowing into or from these waters. ${ }^{105}$ The Crown grant of 1810 contained no reservation of

\footnotetext{
102 Ibid.

103 Ibid.

104 Lord v Commissioners for the City of Sydney (1859) English Reports, 14, 991.

105 Ibid., 992.
} 
water rights but the land was bounded by a small creek. Presumably the grantee as a riparian proprietor was entitled to any common law water rights. The Crown grant of 1823 of land above the land granted by the 1810 grant - above in terms of the flow of any water - contained a reservation of 'any quantity of water ... as might be required for public purposes' provided there was no interference with, injury to or prevention of the working of related water-mills. ${ }^{106}$ The owner of the land which was the subject of the 1823 grant - the 'above' land - had become the owner of the land which was the subject of the 1810 grant - the 'below' land. In 1855 parts of the 1810 and 1823 land grants were resumed by the Crown and the water of the creek associated with the 'above' land appropriated by the Crown. ${ }^{107}$ Was the owner of the 'below' land who was also the owner of the 'above' land entitled to compensation for the removal of water rights associated with the 'above' land?

The argument presented to the Privy Council seems to have been along these lines. ${ }^{108}$ The 1823 grant contained the provision reserving water to the Crown for use for public purposes. This had been acted upon and the water was no longer available to the holder of the 1823 grant. Was the holder of the 1810 grant similarly deprived of any water right dependent upon the flow of water from the upper riparian land? The answer depended upon the extent of the original grant. According to Sir John Coleridge:

If you grant anything, you are presumed to grant, to the extent of your power, that also without which the thing cannot be enjoyed. But what is the effect of this reservation? Ten acres of land in any part of the grant are reserved, at the election of the Crown, if required for public purposes; these are not to be granted to the Crown by Lord [the 1823 grantee], but are provisionally saved out of the grant to him. As to the water, Lord, as owner of the land, had no power to grant it to the Crown; the Crown could not grant any property in it to him, nor he to the Crown; the effect of the saving is only that he waives his own rights as riparian owner to the use of it as it flowed. ${ }^{109}$

To a considerable extent this personalises the saving in relation to the original grantee irrespective of subsequent changes to ownership of the land. The reporter has summarised neatly the essence of this complicated decision:

\footnotetext{
106 Ibid., 993.

107 Ibid., 993-4.

108 Ibid., 1001.

109 Ibid.
} 
That the right to the use of the flowing water of the creek in respect of the land below, originally granted to Redmond [in 1810], was not lost by the acceptance of Lord of the land above [in 1823], although in the latter grant the Crown had reserved the right to take the water, the only effect of the reservation being that Lord waived his own rights as riparian owner to the use of the water as it flowed past his land. ${ }^{110}$

In 1889 in the case of Cooper v Stuart ${ }^{111}$ Lord Watson said this about the Lord Case:

But though the decision is not directly in point, its circumstances throw some light upon the present question. It was an action for compensation under the Sydney Water Act of 1853. The compensation sought and awarded was in respect of putting in force a reservation under a grant of 1810, made by Governor Macquarie in terms identical with the grant of 1823, and the Water Act seems fully to recognise the validity of such reservations. ${ }^{112}$

The person successfully seeking compensation in the Lord Case was not the original grantee of the 1823 grant but rather the devisee of that grant, also named Lord. ${ }^{113}$ This reinforces the individuality of these water rights - entirely consistent with the doctrinal foundations of the common law.

\section{TOWARDS A PUBLIC DOMAIN REGIME IN AUSTRALIA}

\subsection{Policy Developments Towards the End of the Nineteenth Century ${ }^{114}$}

During the nineteenth century water resources governance in Australia was based upon three different approaches: (1) the application of the rules of the common law; (2) the reservation of water rights to the Crown in grants by the Crown of interests in land to individuals; and (3) the

\footnotetext{
110 Ibid., 992.

111 (1889) Appeal Cases, 14, 286. This case is discussed in Section 3.3.

112 Ibid., 294.

113 Lord v Commissioners for the City of Sydney (1859) English Reports, 14, 991, 1001.

114 See generally Fisher, Water Law (n 1), 4-5; Lucy, J. Water Regulation The Laws of Australia (Thomson Reuters 2008), 100; Gardner et al. (n 77), 183-9; and Stoeckel et al. (n 77), 17-18.
} 
enactment of legislation authorising on an ad hoc project basis the construction and use of public works related to the supply of water for public use.

The governance of water resources was thus largely unplanned, uncoordinated and unregulated. Were arrangements such as these impeding the economic and social development of Australia? The three particular areas of political concern were the availability of water for public supply, mining and irrigation. The response was a series of inquiries prompted by a severe drought during the years 1877 to 1881.115 A report of 1871 for the colony of South Australia recognised the problems of 'semi-aridity, rainfall variability and inadequate water storages'. ${ }^{116}$ The solutions to these problems included 'the proper assertion of the public right to all streams throughout the country, and the desirability of at once, if possible, taking the most effectual measures to stop anything approaching to their permanent alienation.' ${ }^{117}$

A similar approach was recommended by the Royal Commission on Water Supply undertaken in 1884 for the colony of Victoria. In these terms: 'It is essential the State should exercise the supreme control of ownership over all the rivers, streams and sources of water supply, except springs arising upon private lands.' ${ }^{118}$ The several colonial legislatures began to respond to these recommendations. The first response emerged as section 4 of the Irrigation Act 1886 of the colony of Victoria in these terms: 'The right to the use of all water at any time in any river stream watercourse lake lagoon swamp or marsh shall for the purposes of this Act in every case be deemed to be vested in the Crown until the contrary is proved.' 119 This, it has been suggested, 'prevented the establishment of further riparian rights and effectively nationalised Victoria's surface waters.' ${ }^{20}$ The other colonies followed with their own legislation but in terms that were not consistent. ${ }^{121}$ The result was - and remains - a somewhat diverse and variable set of arrangements pointing generally in the direction of the public control and regulation of water resources.

\footnotetext{
115 Gardner et al. (n 77), 184.

116 Powell (n 81), 66.

117 Ibid., 68.

118 Gardner et al. (n 77), 184.

119 Ibid., 185.

120 Powell (n 81), 132.

121 Gardner et al. (n 77), 185-9.
} 


\subsection{The Relationship Between the Early Public Control Legislation and the Common Law ${ }^{122}$}

\subsubsection{Introduction}

The legislation was enacted in the context of the approaches adopted by the common law. There emerged, not surprisingly, tensions between perceptions of how water resources should be managed in the public interest and how they should be managed by the individual holders of water rights in their own interest. It is again no surprise that the courts themselves have been challenged by these tensions. The physical, biological and ecological relationships between land and water and the reciprocal consequences of their uses have in most - perhaps in all legal systems presented a range of doctrinal challenges for the courts, certainly in Australia. While the rights of surface landowners are protected by the common law rules of nuisance and to some extent of negligence and the rights of riparian landowners are protected by the common law rules of the riparian doctrine, the creation of a system of public rights in relation to water which impact upon the use of land has compounded the tensions within the common law. This can be demonstrated by a brief review ${ }^{123}$ of how the courts in Australia have responded.

\subsubsection{The 1900 Hanson Case}

Such an issue emerged in 1900 in the Hanson Case. ${ }^{124}$ The litigants were engaged in mining and occupied adjacent land through which a stream flowed intermittently. The lower tenement holder constructed a dam across the stream. The effect was that the water which normally flowed through and away from the land of the upper tenement holder was diverted back and it flowed into mines and shafts of the upper tenement holder. If the common law riparian doctrine applied, the rights of the upper tenement holder would appear to have been infringed. What was the effect of section 1(1) of the Water Rights Act 1896 of New South Wales which stated that '[t]he right to the use and flow and to the control of the water in all rivers and lakes which flow through or past or are situate within the land of two or more occupiers, and of the water contained in or conserved by any works to which this Act extends, shall,

\footnotetext{
122 See generally Fisher, Water Law (n 1), ch. 5; and Gardner et al. (n 77), $193-7$.

123 For a detailed review, see Fisher, Water Law (n 1), 101-122.

124 Hanson v Grassy Gully Gold Mining Co. (1900), New South Wales Reports, 21, 271.
} 
subject only to the restrictions hereinafter mentioned, vest in the Crown'? Section 1(2) provided for the exercise of this right in operational terms: namely the construction and management of the relevant infrastructure. What did section 1(1) mean? According to Justice Stephen: 'I do not think the language of the Act could be clearer, and plainly the rights of the riparian owners were divested and vested in the Crown. ${ }^{125}$ The rights were undoubtedly vested in the Crown but the Act said nothing about the divestment of the rights of the riparian owners. This remained an unresolved issue for decades.

\subsubsection{The 1950 Jones Case}

The issue was debated by the High Court of Australia twice during the 1950s. In the Jones Case ${ }^{126}$ the litigants were not two individuals as in the Hanson Case but a riparian landowner and a local council exercising statutory powers to provide a public water supply. Section 209 of the Local Government Act 1906 of Tasmania vested in each council every river, creek or watercourse within the limits of every water district within the area of the council together with the 'absolute control and regulation of the supply of water' from these sources but subject to 'the previously existing rights of any riparian proprietors to the use of the water flowing into' these sources. In this case the council had taken water from a river at a point located above the land of the riparian landowner to the disadvantage of the riparian landowner. The Chief Justice of Tasmania decided that the riparian rights were diminished to the extent necessary to enable the council to supply water from the stream. ${ }^{127}$ The Chief Justice of the High Court of Australia presented a different analysis:

With much respect to his Honour, it appears to me that this interpretation of section 209 makes riparian rights subject to the exercise of the power of the council to supply water, whereas the section provides that the exercise of the power given to the council is to be subject to the riparian rights of persons who own the land on the banks of the river. ${ }^{128}$

Riparian rights existed side by side with statutory rights. Which rights would have priority, however, was not entirely clear. Much would depend upon the statutory provisions.

\footnotetext{
125 Ibid., 275.

126 H Jones \& Co Pty Ltd v Municipality of Kingborough (1950), Commonwealth Law Reports, 82, 282.

127 Ibid., 302; See also Fisher, Water Law (n 1), 104-105.

128 Ibid.
} 


\subsubsection{The 1955 Thorpes Case}

The litigants in the Thorpes Case ${ }^{129}$ in 1955 were private institutions. Levee banks had been constructed along a creek which flowed into a river that adjoined the land of the upper landowner. This altered the direction of the flow of the water and on occasions caused damage to the lands of the lower landowner for which the affected lower landowner sought a remedy. The upper landowner argued that the action was an action for damages for the infringement of a riparian right and that this riparian right had been removed by the Water Rights Act 1896 of New South Wales. This argument was rejected by the High Court of Australia. The right in question was not a riparian right but a right held by any owner of land. As Justice Fullagar pointed out, the action was 'an ordinary action of nuisance'. ${ }^{130}$

His Honour went on to comment on the effect of the Water Rights Act 1896 of New South Wales in a way different from the approach of Justice Stephen in the Hanson Case, in these words:

The real object of the Water Rights Act 1896, as revealed by the latter part of section 1, was to enable the Crown, in a country in which water is a comparatively scarce and important commodity, to exercise full dominion over the water of rivers and lakes and to undertake generally the conservation and distribution of water. For the attainment of that object it was not necessary to destroy anybody's rights, but it was necessary to give to the Crown, or to some other statutory authority, overriding rights to which private rights must, if need arise, give way. ${ }^{131}$

There are four points critical to this analysis: (1) the importance of the object of the Act; (2) the relevance not only of section 1(1) but also of section 1(2); (3) the use of the expression 'full dominion'; and (4) statutory rights as overriding rights. His Honour expanded upon this analysis in these words:

The view which I am disposed to take is that the Act does not directly affect any private rights, but gives to the Crown new rights - not riparian rights which are superior to, and may be exercised in derogation of, private riparian rights, but that, until those new and superior rights are exercised, private rights can and do co-exist with them. ${ }^{132}$

129 Thorpes Ltd v Grant Pastoral Co Pty Ltd (1955), Commonwealth Law Reports, 92, 317.

130 Ibid., 329.

131 Ibid., 331.

132 Ibid. 
Bearing in mind that this case was decided on the basis of liability in nuisance, a further set of four points emerges: (1) common law rules in relation to riparian rights and liabilities relate only to water and its uses; (2) common law rules in relation to the use of land can relate to associated uses of water; (3) the strategic nature of statutory rights in relation to the use, flow and control of water; and (4) the operational nature of statutory rights in relation to the construction, use and management of infrastructure for water supply

A determination of the relationship between common law and statutory rules is no easy task. It is a reflection of the jurisdiction in question; the precise issue before the court - land based or riparian based; the detail of the common law rules relevant to the action; the terms of the particular statutory provision in question; and the broad structure and object of the legislation in question.

\subsubsection{The 1962 Gartner Case}

The courts in Australia have grappled with these challenges not only at a federal level but also at a state and territory level. ${ }^{133}$ The most authoritative analysis emerged in 1962 with the decision of the High Court of Australia in the Gartner Case ${ }^{134}$ which essentially endorsed the earlier analysis of the court. In this case the litigants were individuals whose interests were private. Their lands were contiguous at certain points. Water gathered on the surface of these lands and flowed across it. A drain had been constructed to assist with the flow of water away from a sand pit operated by the defendant. Barriers were then constructed by the defendant and these barriers impeded the flow of water so that water remained on the plaintiff's land during wet seasons. The plaintiff sought a remedy for an infringement of common law rights. It was decided that the flow of water in the circumstances of this case was not through a watercourse but across the surface of the land. The riparian doctrine did not apply. Liability was determined on the basis of the law of nuisance.

A review of the approach adopted by Justice Windeyer illuminates the range of doctrinal issues underlying the governance of water resources in Australia. His Honour prefaced his comments by referring to the rules of the common law in this way:

These rules are very old. They have been applied in England in innumerable cases to determine and define rights and obligations in relation to streams

\footnotetext{
133 See Fisher, Water Law (n 1), 107-119.

134 Gartner v Kidman (1962), Commonwealth Law Reports, 108, 12.
} 
along the banks of which men have been settled for centuries, using the waters and enjoying the benefits of their flow. ${ }^{135}$

After noting the very different climatic and geographical conditions in Australia, this was the conclusion:

And this is to be borne in mind when particular decisions of English courts are brought forward as analogies. But it is beyond doubt that these rules are a part, and an important part, of the common law that Australia has inherited. ${ }^{136}$

What rules of the common law were relevant in this case? Not riparian rules but those relating to nuisance because of the particular circumstances of this case. It was necessary to identify a right which had potentially been infringed. As his Honour explained:

In considering whether there has been an actionable interference with the beneficial enjoyment of land, it is necessary, in every case, to know whether some particular right in or in relation to that land is said to have been invaded, and if so to ascertain the limits of that right. ${ }^{137}$

The relevant question was whether the common law recognised a right to obstruct the natural flow of water and the circumstances in which such a right could be exercised. Justice Windeyer reviewed earlier judicial discussion and stated:

The fundamental rule is, I think, the reverse of what Chief Justice Madden in Vinnicombe $\mathrm{v}$ MacGregor ${ }^{138}$ stated it to be. He said that the lower owner cannot obstruct the natural flow of surface water unless he can and does so in a manner which will not injure the upper land. On the contrary the law is, I think, that he may block it by any works on his own land, so far as they are reasonably necessary to protect his land for his reasonable use and enjoyment; but that in doing so he must not act recklessly of his neighbour so as to cause wanton damage to him. That, in my opinion, accords with the broad principles of the law of nuisance today. ${ }^{139}$

Justice Windeyer responded to the Chief Justice's analysis by translating a negative obligation coupled with a positive but conditional right into a positive right coupled with a negative but conditional obligation. These rights and obligations relate to the use of land and the impact of such a

\footnotetext{
135 Ibid., 23.

136 Ibid.

137 Ibid., 38-9.

138 (1902) Victorian Law Reports, 28, 144.

139 Gartner v Kidman (1962) Commonwealth Law Reports, 108, 12, 46.
} 
use of land. The circumstances in which they can arise include activities involving water and by association such activities impacting on land: namely, a doctrinal interface between water and land - a concept thousands of years old. Perhaps in this way:

There is, in other words, a fundamental recognition of the mutuality of interests of adjacent landowners and occupiers, protected by the law of nuisance, just as the law protects the mutual rights and interests of riparian proprietors by the common law riparian doctrine. There is no absolute right to deal with the land in an unrestricted way. This is so, not only in relation to the land itself, but also in relation to any interference with the flow of water across the land as a result of activities on the land. ${ }^{140}$

\subsubsection{Conclusion}

There can be little doubt that the rules of the common law had not been automatically extinguished by the creation of a Crown right to the flow, use and control of water. Each set of circumstances, each rule of the common law and each statutory provision would need to be analysed, interpreted and applied both separately and together so that the relationship between all of the relevant elements of the legal system could be viewed consistently and coherently. Not an easy task. This is no doubt the reason why some jurisdictions later in the twentieth century specifically abolished common law rights in relation to water. Now is the time to turn to a more detailed assessment of the current legislation in Australia.

\subsection{An Analysis of Current Australian Legislation}

\subsubsection{The constitutional framework ${ }^{141}$}

It is important to note that, after the establishment of the federal Commonwealth of Australia in 1900 until 2007, the management of water resources had been undertaken in accordance with the legislation of the states and territories - that is the former colonies. In a negative sense this principle of state legislative exclusivity was recognised by the inclusion of section 100 in the Commonwealth Constitution which states that 'The Commonwealth shall not, by any law or regulation of trade or commerce, abridge the right of a State or of the residents therein to the reasonable use of the waters of rivers for conservation or irrigation.' 
The right in relation to water recognised in this way - probably in the context of interstate rivers - is protected by the duty imposed on the Commonwealth not to interfere with it in the exercise of the power of the Commonwealth to enact laws concerning trade or commerce. Justice Mason of the High Court of Australia has commented that the relationship between the water and the trade and commerce provisions suggests that ' $[t]$ he primary purpose of section 100 was to safeguard the rights of a State and its residents to the use of waters and rivers used for interstate trade and commerce including navigation and shipping, viz the Murray River.' ${ }^{142}$

The Constitution of the Commonwealth otherwise makes no reference to water. If the Commonwealth were minded to become involved in water resources governance, it either seeks a referral of legislative power from the states or exercises somewhat indirectly a potentially relevant power over another matter. For example, powers in relation to:

- trade and commerce with other countries and among the states water as a commodity,

- trading corporations formed within the limits of the Commonwealth - corporations trading in water resources,

- external affairs - implementing international obligations,

- grants of financial assistance to any state.

The grant of financial assistance and the implementation of international obligations have become important examples of Commonwealth involvement in water resources governance. The Water Act enacted by the Commonwealth in 2007 - the most important legislation enacted by the Commonwealth about water - relies largely upon the referral of powers by the states and to a lesser extent on the other sources of legislative authority. The Act of 2007 creates a planning and management regime for the Murray-Darling Basin - a very large and important interstate water catchment area responsible for a considerable part of Australia's agricultural production. ${ }^{143}$ The Murray-Darling Basin Plan is formulated

142 Commonwealth v Tasmania (1983) Commonwealth Law Reports, 158, 1, 241.

143 For a detailed discussion see Fisher, D. 'A Sustainable Murray-Darling Basin: the Legal Challenges' in D. Connell and R. Quentin Grafton (eds), Basin Futures - Water Reform in the Murray-Darling Basin (ANU E Press 2011). 
under the Act but it is given effect through the legal arrangements in the states. The legal nature of the legal arrangements in the states remains critical.

\subsubsection{The generic elements of the water legislation in Australia}

The legislation of the nine jurisdictions in Australia ${ }^{144}$ is broadly similar in content, reflective of how legal rules for the governance of natural resources and the environment are evolving to meet the challenges of sustainability, but often different in terms of form and language. ${ }^{145}$ Apart from the residual but important functions of the common law, water resources governance is essentially statutory. This is no surprise given that the function of legislation is often to formalise what is perceived to be in the public interest - the essence of a public domain regime. The structure, form and language of the legislation are critical to its interpretation and application. ${ }^{146}$ Hence the need to assess the structure and text of a number of examples.

The end of the nineteenth century saw the emergence of the foundations of a public domain regime in Australia with the conferment on a public authority of a statutory right to the flow, use and control of water in watercourses - hereafter the 'foundational' right of the state. This, it has been noted, created a new right alongside existing common law rights without automatically extinguishing them but overriding them in some circumstances. During the twentieth century and, most importantly, at the beginning of the twenty-first century a comprehensive range of legal rules developed further the idea of the public domain. In some jurisdictions this included the complete or partial abolition of common law rights in relation to water. Their ultimate objective has been to achieve the sustainable use and development of water resources.

What has emerged is a range of structures each with some of these elements: (1) the foundational right of the state; (2) a statement of the objectives of the legislation - sometimes supported by a duty to achieve them - hereafter the objects; (3) a statement of the principles for managing water - sometimes supported by a duty to be guided by them hereafter the principles; (4) the formulation of a plan or a series of plans for managing the water; (5) a duty not to take or use water without a

\footnotetext{
144 Namely the Commonwealth, the six states and the two territories.

145 Fisher, D. 'Delivering the National Water Initiative - the emergence of innovative legal doctrine' in K. Hussey and S. Dovers (eds), Managing Water for Australia - the social and institutional challenges (CSIRO Publishing 2007), 115.

146 See generally Fisher, D. Legal Reasoning in Environmental Law - a Study of Structure, Form and Language (Edward Elgar Publishing 2013).
} 
licence, an approval or other form of authorisation; (6) an individual right to take or use water or to receive water in accordance with such an authorisation; (7) a statutory right conferred upon individual landholders to take or use water for specific purposes - analogous in some respects to common law riparian rights; (8) arrangements for transferring water rights; and (9) arrangements for environmental water entitlements. ${ }^{147}$

No jurisdiction contains all of these instruments. It has been concluded that:

these arrangements disclose a set of mosaics or patterns that are structurally linked in different ways, but each lead to the sustainable use and development of water resources in one form or another. While there is no thematic or doctrinal consistency - let alone uniformity - each set of arrangements strive to achieve its objectives in its own way. ${ }^{148}$

\subsubsection{The functions of the foundational right, objects, principles and plans}

Consider, first, the relationship between the foundational right of the state and its associated objects and duties. Section 19 of the Water Act 2000 of Queensland states that 'all rights to the use, flow and control of all water in Queensland are vested in the State'. This 'right' is in the nature of a power. The exercise of this right or power is not unlimited. It is controlled in two ways:

1. by the purpose stated in section 10(1);

2. by the duty imposed by section 12 upon all entities to perform their functions or to exercise their powers in a way that advances the purpose stated in section 10(1).

According to section 10(1), the purpose is to advance sustainable management and efficient use of water and other resources by establishing a system for the planning, allocation and use of water. The terms 'sustainable management' and 'efficient use' are defined in some detail. ${ }^{149}$ Although it is ultimately the responsibility of the state to ensure that the planning, allocation and use of water achieve the purpose of the Act, the implication of section 12 is that everyone shares a common responsibility to do so because everyone is performing statutory functions or exercising statutory powers - if not directly, at least indirectly because

\footnotetext{
147 For more detail see Fisher (n 145), 116-20.

148 Ibid., 120.

149 Water Act 2000 (Queensland), s. 10(2) and (3).
} 
the Act is the source of all authority in relation to water resources governance.

Consider, second, the relationship between the management principles that guide the exercise of statutory powers and their associated objects, duties, plans and specific rules. Section 392 of the Water Management Act 2000 of New South Wales creates the foundational right; section 393 abolishes common law riparian rights; section 3 states the objects of the Act; and section 9 imposes a duty in relation to the management principles set out in section 5. The object of the Act is directed at sustainable development which is achieved by applying the associated management principles. Section 5(3)(a) states as a principle that 'sharing of water from a water source must protect the water source and its dependent ecosystems.' Section 9(1)(b) states:

[i]t is the duty of all persons exercising functions under this Act:

(b) as between the principles for water sharing set out in section 5(3), to give priority to those principles in the order in which they are set out in that sub-section.

These provisions have attracted judicial comment.

In the Nature Conservation Council Case in 2005, ${ }^{150}$ the issue was the validity of a clause in a water management plan which contained environmental rules. These rules were to identify planned environmental water which is water 'committed' for fundamental ecosystem health. The clause in question prohibited the taking of water from the source in question in excess of the long term average annual extraction. The Court of Appeal in New South Wales took the view that 'virtual' rather than 'real' water had been 'committed' to protect 'fundamental ecosystem health' ${ }^{151}$ The clause in the rules was formally invalid because priority had not been given to fundamental ecosystem health. The water management plan, however, was valid because it achieved substantively the objects of the Act. Here is the reason:

The objects of the Act set out in section 3(a) and section 3(b), the water management principles set out in section 5(2)(a) to (d) and section 5(3)(a), together with a priority established by section $9(1)$ (b) strongly suggest that the

150 Nature Conservation Council of New South Wales Inc v Minister Administering the Water Management Act 2000 (2005) New South Wales Court of Appeal 9.

151 Ibid., paras. 65-6. 
Parliament was concerned with matters of substance rather than form when it required the establishment of environmental water rules. ${ }^{152}$

The importance of this decision is the way in which the court interpreted and applied the language in the Act which expressed the relationship between the objects, the management principles, the duty in relation to these principles and the provision in the rules - a complex set of concepts but clearly stated in the legislation.

\subsubsection{An integrated model for water resources governance}

Consider a different model: namely, a fully integrated, planning and regulatory regime for natural resources governance of which water resources are a critical part. The Natural Resources Management Act 2004 of South Australia does not prescribe a foundational right of the state. It is a combination of objects, principles, general duties, more specific duties, plans, rights, restrictions on the exercise of rights, and supporting administrative procedures. The foundation upon which the Act is constructed is the set of objects and principles declared in section 7. In the context of water resources, section 7(1)(c) provides:

The objects of this Act include to assist in the achievement of ecologically sustainable development in the State by establishing an integrated scheme to promote the use and management of natural resources in a manner that provides for the protection and management of catchments and the sustainable use of land and water resources and, insofar as is reasonably practicable, seeks to enhance and restore or rehabilitate land and water resources that have been degraded.

Significantly, this provision incorporates several related objects or outcomes: (1) ecologically sustainable development; (2) promotion of the use of natural resources; (3) protection of catchments; (4) sustainable use of water resources; and (5) restoration of degraded water resources.

Section 7(2) goes on to define ecologically sustainable development in a way that links economic, social and ecological outcomes. Section 7(3) states in great detail the principles that 'should be taken into account in connection with achieving ecologically sustainable development for the purposes of this Act'. The principle in section $7(3)(\mathrm{k})$ is particularly significant. Namely the responsibility to achieve ecologically sustainable development should be seen as a shared responsibility between the public sector, the private sector, and the community more generally. The notion

\footnotetext{
152 Ibid., para. 95.
} 
of shared or common responsibility is a reflection of water resources as common resources.

The achievement of the objects of the Act is facilitated by the creation of three duties in descending order of specificity: (1) the overriding duty in section 8 in relation to the objects of the Act; (2) the duty imposed by section 9(1) on all persons to 'act reasonably in the management of natural resources within the State' supported by the criteria in section 9(2) for determining what is reasonable; and (3) the duty imposed by section 133(1) on 'the owner of land' situated on or adjoining 'a watercourse or lake to take reasonable measures to prevent damage' to their beds, banks or shores and 'to the ecosystems that depend on the watercourse or lake'.

The duty in section 8 requires further analysis. It states:

The Minister, the Court and all other persons or bodies involved in the administration of this Act, or performing, exercising or discharging a function, power or duty under this Act, must have regard to, and seek to further, the objects of this Act.

The duty applies effectively to every person and institution in the state. It is imposed not only on those involved in administration but also on those seeking authorisation for or engaging in an activity to which any provision in the Act applies. It is a duty of comprehensive and probably total application. The duty, however, is not absolute. It is limited to having regard to the objects of the Act and to seeking to further them. The duty to 'have regard' is certainly justiciable. Whether the duty to 'seek to further' is justiciable is less clear. In any event each of these three duties sends a clear message to everyone involved in the management of natural resources - including water resources - particularly when they are applied in conjunction with the principle of common responsibility.

It is against this background that the range of rights and regulatory arrangements needs to be discussed. The range of rights is extensive. Section 124(8) abolishes rights at common law in relation to the taking of naturally occurring water. In substitution, water rights are conferred by section 124. First, a person who has lawful access to a watercourse, lake or well may take water therefrom for any purpose. ${ }^{153}$ Second, the occupier of land is entitled to take surface water from the land for any purpose. ${ }^{154}$ However, if the watercourse, lake or well is prescribed or the

153 Natural Resources Management Act 2004 (South Australia), s. 124(1).

154 Ibid., s. 124(2). 
area is a prescribed surface water area, then either an authorisation under section 128 or a water allocation is required. ${ }^{155}$ If the watercourse, lake or well is not prescribed, water must not be taken if - to paraphrase - the interests of others are detrimentally affected. ${ }^{156}$ However, the right of the occupier of land to take water from a watercourse, lake or well or water that is surface water is not restricted by these provisions provided the water is used by the occupier for domestic purposes or for watering stock but not stock subject to intensive farming. ${ }^{157}$ These rules are in some respects a statutory reflection of those of the common law.

There are two types of regulatory arrangements: water resource planning and control of water related activities. There are obligations to prepare three types of plan:

- a State Natural Resources Management Plan, ${ }^{158}$

- a regional natural resources management plan for each region, ${ }^{159}$

- a water allocation plan for each of the prescribed water resources in each region. ${ }^{160}$

Unless there is in force an authorisation or a water allocation, water must not be taken contrary to the provisions of a regional or a water allocation plan. ${ }^{161}$ There is accordingly a hierarchical relationship between these three types of plan and the statements of objects and principles in section 7 supported by the range of duties imposed by sections 8, 9 and 133 .

The range of water and water related activities controlled is very extensive. Activities affecting water include taking water from a prescribed source and those involving wells, dams and similar structures. ${ }^{162}$ The range of relevant instruments designed to grant approval to water and water related activities includes: (1) well driller licences; ${ }^{163}$ (2) water licences; ${ }^{164}$ (3) water allocations; ${ }^{165}$ (4) water resource works

$\begin{array}{ll}155 & \text { Ibid., s. 124(3)(a). } \\ 156 & \text { Ibid., s. 124(3)(b). } \\ 157 & \text { Ibid., s. 124(4). } \\ 158 & \text { Ibid., s. 74. } \\ 159 & \text { Ibid., s. 75. } \\ 160 & \text { Ibid., s. 76. } \\ 161 & \text { Ibid., s. 124(7). } \\ 162 & \text { Ibid., s. 127(1) and (3). } \\ 163 & \text { Ibid., s. 139. } \\ 164 & \text { Ibid., s. 146. } \\ 165 & \text { Ibid., s. 152. }\end{array}$


approvals; ${ }^{166}$ (5) site use approvals; ${ }^{167}$ and (6) delivery capacity entitlements. ${ }^{168}$

What emerges from these arrangements for water resources governance in South Australia is the integration of water resources management into a system of natural resources governance directed at their ecologically sustainable development. These arrangements include an obligation to take into account the evolving set of principles in support of sustainability. The capacity of the system to ensure compliance - always a major challenge - relies upon the duties imposed upon the community at large to move in the direction of ecologically sustainable development. Equally important are the water rights conferred upon everyone, while the exercise of these rights is controlled by a very comprehensive planning regime and an equally extensive number of detailed sets of circumstances requiring administratively granted approval. Despite the absence of a foundational right conferred on the state, these arrangements reflect most - perhaps all - of the features of a public domain system. There can be little doubt that the legislature has determined that ecologically sustainable development is in the public interest and that these arrangements can go some way to achieve it.

\section{CONCLUSION}

\subsection{From Common Resources to an Institutionalised Public Domain}

Water resources have traditionally been regarded as common resources to be used for the benefit of the community at large. From a legal perspective, they may be regarded as res communes - common not private property. This was part of the approach stated in the Institutes of Justinian. It was modified towards the end of the Roman empire, when the management of water resources was institutionalised by the introduction of supporting administrative arrangements - the emergence of a public domain regime. Although the common law was influenced by the doctrinal foundations of Roman law, it did not evolve into a public domain regime. The rules of the common law essentially granted rights of access to water to eligible landowners and occupiers and to be used for private rather than public purposes. The reluctance of the common law to

\footnotetext{
166 Ibid., s. 159.

167 Ibid., s. 164A.

168 Ibid., s. 164G.
} 
grant rights of access to water to be used for public purposes was solved by the enactment of legislation authorising the construction of water infrastructure and in some cases access to water and its use for public purposes. This model began to be adopted in England in the late eighteenth century and later in the colony of New South Wales. In New South Wales, in addition, water rights were reserved to the Crown in grants of interests in land to individuals. Finally, in Australia, the Crown - thereafter the state - was invested with the foundational right to water. This led to the emergence of an inchoate public domain regime in Australia.

In these various ways the management of water resources in Australia was institutionalised along the lines of a public domain regime. There developed a set of private rights and a set of public rights. The relationship between them presented doctrinal challenges to the courts. The exercise of common law rights of access to water changes the status of the water abstracted in this way from a res communis to a res propria or a res privata. The institutional arrangements associated with a public domain regime facilitate the management and use of water in the public interest. The relationship between the rules supporting the management of water in the public interest and the rules of the common law protecting the rights of individuals has been discussed in a number of cases in the courts. The most recent analysis undertaken by the High Court of Australia was the Thorpes Case in $1955^{169}$ until the court took the opportunity to consider the doctrinal foundations of water law in the ICM Case in 2009. ${ }^{170}$ Did the court acknowledge the emergence of a public domain regime in Australia?

\subsection{Judicial Endorsement of Water Resources as Common Resources}

The issue in this complicated case was whether variations made to water plans and consequential reductions in the quantity of water available for irrigation under water entitlements granted under the New South Wales legislation in accordance with a scheme partly funded by the Commonwealth constituted an acquisition of property other than on just terms

169 Thorpes Ltd v Grant Pastoral Co Pty Ltd (1995), Commonwealth Law Reports, 92, 317. See the discussion in Section 4.2.4 above.

170 ICM Agriculture Pty Ltd v Commonwealth (2009), Australian Law Journal Reports 84, 87. 
contrary to section 51(xxxi) of the Commonwealth Constitution. ${ }^{171}$ This was a very complex issue but one which raised questions about the status of water under the common law and under the statutory regimes that had emerged in Australia. In particular:

The tension in relation to water resources between, on the one hand, the public interest in ensuring that water resources are used and developed sustainably for the future and, on the other hand, the need to protect private interests in the use of water resources in the context of the rights of existing users - in this case, irrigators. ${ }^{172}$

How did the court respond? Given the provision in the Constitution about 'acquisition of property', it is no surprise that water as property was discussed. This was the first response:

First and foremost, there was then [in the nineteenth century], and still must be, a clear recognition of the difficulty of applying notions of ownership or property to water in the ground or in a flowing stream. What exactly would be the subject of property rights? While still allowed to flow, no part of the water that flows in the stream can be isolated and tagged as the water 'owned' by some person. And water in the ground may move more slowly but there is no less difficulty in identifying what would be the subject of the proprietary rights. ${ }^{173}$

This was the second response:

Next, even if these difficulties of identifying the object in respect of which proprietary rights were to exist could be overcome, should any proprietary right be recognised? ${ }^{174}$

The first response was an acknowledgement of hydrological reality. The second raised a fundamental issue of principle. How was it resolved?

It was accepted that water exists in its natural state for the common benefit of humans. Accordingly, it has been suggested, "while the common law recognised individual or private rights of access in relation

171 There is no discussion here of the complex constitutional issues that arose in this case. These are discussed in Fisher, D. 'Water law, the High Court and techniques of judicial reasoning' (2010) Environmental and Planning Law Journal 27, 85-97.

172 Fisher (n 171), 89.

173 ICM Agriculture Pty Ltd v Commonwealth (2009), Australian Law Journal Reports 84, 112.

174 Ibid., 113. Emphasis added. 
to water, they were based upon water as common property.' ${ }^{175}$ This was certainly not a novel proposition. The court itself referred to the riparian doctrine that emerged in the nineteenth century and concluded:

The underlying proposition was that water, like light and air, is common property (for the common benefit of man). ${ }^{176}$

The common law, however, was silent about how to ensure that water was collected and used 'for the common benefit of man'. Hence, as noted on several occasions, the need for institutionalised arrangements to promote the public interest in the management of water resources. The court then addressed whether the statutory arrangements introduced since the end of the nineteenth century did so.

It will be recalled that in the Thorpes Case in 1955, Justice Fullagar said that the 'real object' of the Water Rights Act 1896 of New South Wales was to give the Crown 'full dominion' over water. The Oxford English Dictionary describes dominion as sovereignty or lordship. In 2009 the court explained further that:

The vesting of rights to the 'use' and 'control' of water constituted an exercise of sovereignty in the sense that the rights so vested were based on the political power of the state. ${ }^{177}$

The exercise of political power would normally be taken to be a reference to its exercise for the public benefit. So, in this case, the question was the nature of the issue before the court: protection of private interests or promotion of the public interest. The court responded in these words:

Finally, it is of the very first importance to recognise that the common law principles established in the nineteenth century were directed to the adjustment of rights between landowners. The issue in this case arises, not because there has been some adjustment of those rights, but because the polity has sought to regulate generally the access allowed to a common resource. ${ }^{178}$

\footnotetext{
175 Fisher (n 171), 91.

176 ICM Agriculture Pty Ltd v Commonwealth (2009), Australian Law Journal Reports 84, 109.

177 Ibid., 54.

178 Ibid., 115.
} 
The institutions exercising power on behalf of the 'polity' represent the means to ensure water resources as common resources are used for the common benefit of humans. Perhaps this synthesises the result:

The High Court has told us that water resources - either from the point of view of the common law or of the public domain regime created by the legislation - are quintessentially common resources or common property. Any private interests in or in relation to water derive from that source and from no other source. ${ }^{179}$

\subsection{A Synoptic Analysis}

Perhaps in these terms:

- water is and always has been a common resource;

- as such it is common not private property;

- it is to be used for the common benefit;

- the common law protects the private rights of individuals to water;

- the exercise of common law rights may indirectly benefit the public as well as the individual;

- the foundational right of the state and its associated administrative arrangements are the means by which water as a common resource is used for the common benefit.

179 Fisher (n 171), 97. 